\title{
Differences in the Food of the Young and the Adult Indian Mackerel, Rastrelliger kanagurta (Cuv.)
}

THe problem of the food of fishes with its varied bearings on their shoaling habits and migrations has engaged the attention of fishery biologists since the beginning of the present century. The mackerel is an important food fish in both hemispheres. Several contributions $^{1-5}$ have been made to our knowledge of the food of the Indian mackerel, Rastrelliger kanagurta, which contributes to one of the largest fisheries of India. All these observations, except those of Chacko ${ }^{3}$, which are from the Gulf of Manaar, are confined to the west coast of India. According to these workers, mackerel is a noted plankton feeder, securing its food by filtration. Chidambaram², while observing the adult mackerel as plankton feeder, suggested the carnivorous habits of the young mackerel. Later, in a detailed account on the food of this fish, Bhimachar and George ${ }^{4}$ observe that "the food of the young mackerel does not radically differ from that of the adult". Pradhan ${ }^{5}$ has arrived at a similar conclusion regarding the food of mackerel ; but one will not fail to note from his observations that young mackerel less than $89 \mathrm{~mm}$. in total length are not represented in his material.

In the course of the present investigation, extend. ing for more than a year, 593 mackerel belonging to all sizes ranging from $32 \mathrm{~mm}$. to $243 \mathrm{~mm}$. in total length have been collected from the Lawson's Bay landings near Waltair, and their food contents examined. From this analysis it became evident that mackerel of the size of $90 \mathrm{~mm}$. and more in total length are plankton feeders, consuming large quantities of Protophyta (phytoplankton) along with some zooplankton. Further, it was noted that the adult mackerel is not an indiscriminate feeder. Though the proportions of the phyto- and zoo-planktonic elements in the stomach contents of this fish are more or less in accordance with their relative abundance in the planktion, a sort of selective feeding (avoidance) exists at least with regard to such macroplanktonic forms such as medusæ, ctenophores, salpe and 


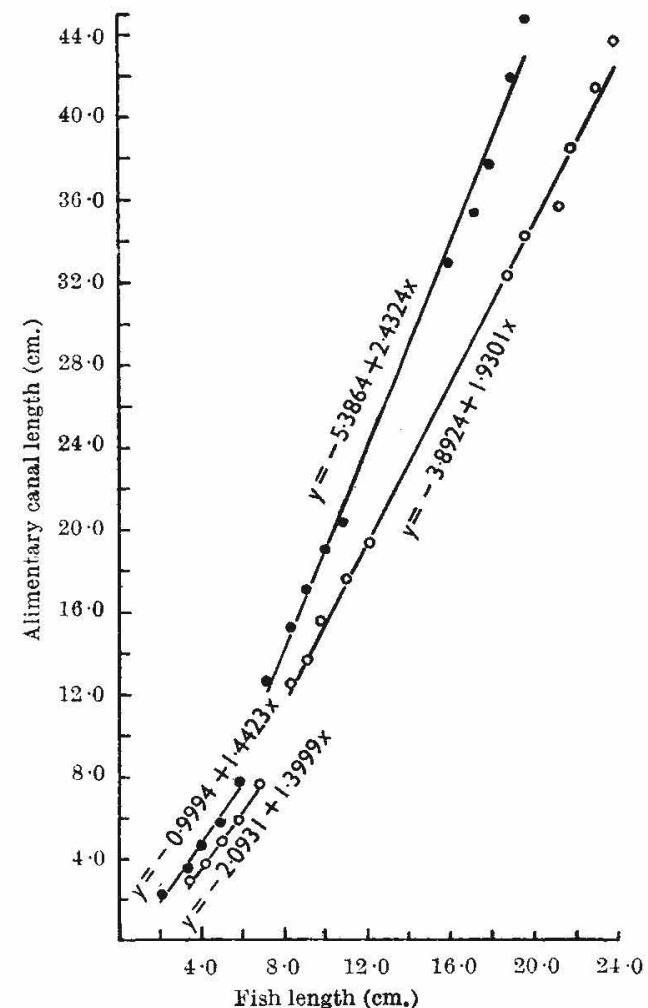

Fig. 1. Number of fish measured, 575 ; all measurements were group 9 d at $1-\mathrm{cm}$. class-intervals and each point represents tho average value for each $1-\mathrm{cm}$. class. The straight line in each case presents the best flt as calculated from the equation given Standard length alongside.

The

I.

five and the remaining ten points is significant at the 5 per cent level of $\chi^{8}$

for nine degrees of freedom.

Taking thength against alimentary canal length, $-\mathrm{O}-\mathrm{O}$.

Taking the Arst ive values as normal (that is, $y=-2 \cdot 0931+$

the remaining eleven of $x^{2}$ for eleven degrees of freedom

chaetognaths. In the stomach contents of mackerel of size-range $90-243 \mathrm{~mm}$. total length, relatively little zooplankton was found and this consisted of the following forms: copepods, larval cirripeds, larval pelecypods, Lucifer, Evadne and larval crustaceans.

The food habits of juvenile macizerel ranging in total length from 32 to $90 \mathrm{~mm}$. are different. The stomach contents of these juvenile fish showed that fish larvæ (Anchoviella species) form their staple food, and this is supplemented by the planktonic sergestid, Lucifer. In rare cases, copepods and a few Protophyta were noted in the stomach contents. These observations suggest that the juvenile mackerel are carnivorous and selective in their food habits.

While making biometrical studies on some marine fishes of the Waltair coast, we have observed an allometric growth in the alimentary canal of the mackerel. The relationship between the linear measurements of the alimentary canal and total and standard lengths of the mackerel is plotted in Fig. 1. It is clear from the graph that the relative length of the digestive tract is greater in the adult fish than in the juveniles. It is interesting to note that both the change in the food habits of the fish and the relative length of its alimentary canal take place at the same total length of fish. It is very likely that this change in the relative length of the alimentary canal of the mackerel is associated with the change in the food habits of the fish at about $90 \mathrm{~mm}$. total length.

We thank Mr. K. Krishna Rao for his help in the statistical treatment of the results presented here.

K. V. Narayana RAO*

K. Pampapathi Rao

Department of Zoology,

Sri Venkateswara University,

Tirupati, Andhra State.

* Present address: Central Marine Fisheries Research Station, West Hill, Khozikode, S. India.

t Devanesan, D. W., and John, V., Curr. Sci., 9, 462 (1940).

${ }^{2}$ Chidambaram, K., Curr. Sci., 13, 214 (1944).

${ }^{3}$ Chacko, P. I., Proc. Ind. Acad. Sci., 29, 83 (1949).

${ }^{4}$ Bhimuchar, B. S., and George, P. C., Proc. Ind. Acad. Sci., 36, 105 (1952).

${ }^{5}$ Pradhan, L. B., Ind. J. Fisheries, 3, 141 (1958). 